\title{
Reserva Imbassaí Restinga: inventory of snakes on the northern coast of Bahia, Brazil
}

\author{
Ricardo Marques ${ }^{1}$, Moacir S. Tinôco ${ }^{2}$, Danilo Couto-Ferreira ${ }^{3}$, Cecil Pergentino \\ Fazolato ${ }^{4}$, Henrique C. Browne-Ribeiro ${ }^{5}$, Magno L.O. Travassos $^{6}$, Marcelo A. Dias ${ }^{7} \&$ João Vitor \\ Lino Mota ${ }^{8}$
}

\author{
${ }_{1,3,4}$ Graduando em Ciências Biológicas, Universidade Católica do Salvador - UCSal. Av. Prof. Pinto de Aguiar, 2589, CEP 41.740- \\ 090, Pituaçu, Salvador, BA, Brasil. \\ 1,2,3,4,5,7,8 Centro de Ecologia e Conservação Animal - ECOA/UCSal. \\ ${ }^{2}$ Docente do Instituto de Ciências Naturais e da Saúde da UCSal. Biodiversity Management PhD Candidate - DICE, Department of \\ Anthropology and Conservation, Marlowe Building, The University of Kent at Canterbury, Kent, CT2 7NZ. \\ ${ }^{6}$ Mestrando em Ecologia e Biomonitoramento, Universidade Federal da Bahia (UFBA). Rua Barão de Jeremoabo, s/n, CEP 40.170- \\ 115, Ondina, Salvador, BA, Brasil. \\ ${ }^{7}$ Mestrando em Zoologia - PEDECIBA, Universidad de la República Uruguay. Oficinas Centrales, Av. 18 de Julio 1968, Montevideo, \\ Uruguay. \\ ${ }^{5} \mathrm{MSc}$ em Ecologia e Biomonitoramento - UFBA. \\ $1,2,3,4,5,7,8,8$ Lacerta Ambiental - Lauro de Freitas, Bahia, Brazil. \\ Email: ${ }^{1}$ rcdmarquess@gmail.com (corresponding author), ${ }^{2}$ mst8@kent.ac.uk, ${ }^{3}$ danilocoutoferreira@gmail.com, \\ ${ }^{4}$ fazolato.cp@gmail.com, ${ }^{5}$ henriquebrowne@gmail.com, ${ }^{6}$ magnotravassos@yahoo.com.br, ${ }^{7}$ biomarcelodias@yahoo.com.br, \\ 8joaovitormota@yahoo.com.br.
}

Date of publication (online): 26 November 2011 Date of publication (print): 26 November 2011 ISSN 0974-7907 (online) | 0974-7893 (print)

Editor: Harold Heatwole

\section{Manuscript details:}

Ms \# 02812

Received 21 May 2011

Final received 21 September 2011

Finally accepted 10 October 2011

Citation: Marques, R., M.S. Tinôco, D. CoutoFerreira, C.P. Fazolato, H.C. Browne-Ribeiro, M.L.O. Travassos, M.A. Dias \& J.V.L. Mota (2011). Reserva Imbassaí Restinga: inventory of snakes on the northern coast of Bahia, Brazil. Journal of Threatened Taxa 3(11): 2184-2191.

Copyright: (c) Ricardo Marques, Moacir S. Tinôco, Danilo Couto-Ferreira, Cecil Pergentino Fazolato, Henrique C. Browne-Ribeiro, Magno L.O. Travassos, Marcelo A. Dias \& João Vitor Lino Mota 2011. Creative Commons Attribution 3.0Unported License. JoTT allows unrestricted use of this article in any medium for non-profit purposes, reproduction and distribution by providing adequate credit to the authors and the source of publication.

For Author Details, Author Contribution and Acknowledgements see end of this article.

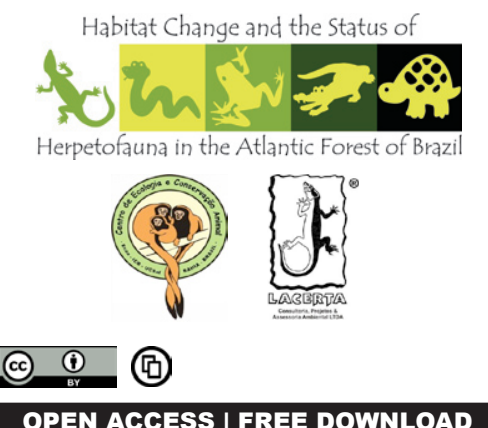

Abstract: Restinga is a coastal ecosystem covering almost the entire Brazilian coast line and it is associated with the Atlantic Forest biome and therefore is a complementary component of the landscape. Its vegetation is highly variable and specialized, being influenced by salt, and with low fertility and moist soil. This environmental landscape promotes the colonization of species from contiguous biomes and ecosystems, thereby promoting high diversity, especially on the northern coast of Bahia. The study was conducted at the Reserva Imbassaí, in the municipality of Mata de São João, northern coast of Bahia, Brazil. We conducted six surveys distributed over one year, with samples every two months; we used the sampling techniques of active visual search, random encounters and pitfall traps along a linear transect. Fourty-nine snakes from 15 species distributed among five families were recorded: Boidae (2), Colubridae (3), Dipsadidae (6), Elapidae (1) and Viperidae (3). Ten of the species of snakes found at Reserva Imbassaí complement the literature overall snakes' list from the north coast of Bahia's restinga. The results show that Reserva Imbassaí is uniquely rich in snakes and therefore represents an important contribution to the knowledge of this taxon within the Atlantic forest hotspot.

Keywords: Atlantic forest, boids, colubrids, dipsadids, elapids, northeastern Brazil, squamata, viperids.

Portuguese Abstract: A restinga é um ecossistema costeiro, cobrindo grande parte da costa brasileira e é associado ao bioma da Mata Atlântica, agindo como componente complementar da paisagem. Sua vegetação é bastante variada e especializada, influenciada pela salinidade marinha e pela baixa fertilidade e umidade do solo. Estes componentes da paisagem contribuem para a colonização de espécies de outros biomas e ecossistemas próximos, tornando-o assim bastante diverso, principalmente no litoral norte da Bahia. Este estudo foi realizado na Reserva Imbassaí, localizado no município de Mata de São João, litoral norte da Bahia, Brasil. Realizamos seis coletas durante um ano a cada dois meses; utilizamos a procura visual ativa, armadilhas de interceptação e queda e encontros ocasionais em um transecto linear. Foram registradas 49 serpentes de 15 espécies das cinco famílias: Boidae (2), Colubridae (3), Dipsadidae (6), Elapidae (1) e Viperidae (3). Dez destas espécies de serpentes encontradas na Reserva Imbassaí complementam a lista de espécies deste grupo para a restinga do litoral norte da Bahia. Os resultados evidenciam que a Reserva Imbassaí possui uma riqueza única de serpentes e representa uma importante contribuição para o conhecimento deste táxon no hotspot da Mata Atlântica. 


\section{INTRODUCTION}

The restinga ecosystem covers almost the entire coast of Brazil and it is associated with the Atlantic rainforest. It lies along the coastal seashore of the Atlantic Ocean, and it is composed of sand dunes deposits, which created coastal dunes after the last marine transgressions and regressions in the quaternary period, over 15,000 years ago (Assumpção \& Nascimento 2000; Menezes 2007).

Although some authors state that from the structural point of view the areas of the Restinga can be considered an homogeneous landscape (Campos \& Domingez 2010), others state that there is important variation in biodiversity (Marques \& Sazima 2004; Rocha et al. 2004); this suggests that when discussing Restinga one should consider both issues. Its vegetation is highly variable and specialized, reflecting the influence of salt, low fertility and low moisture of the soil, thereby promoting xerophytic vegetation (Tonhasca 2005) similar to that found in the Caatinga (Brazilian dry lands) and Cerrado (Brazilian grasslands), contiguous with the Atlantic Forest within the region.

The ecosystem is well distributed on all the northern coast of Bahia, covering nearly $220 \mathrm{~km}$, from the capital city, Salvador, apparently beginning at the Farol da Barra to the northern border to the State of Sergipe where the river, locally known as Real River, imposes effective isolation by forming a geographical barrier to the north. Seven protected areas (PA) are found within the region, and four other have been proposed, due to the high scale of habitat loss caused by tourism and urban development (Tinôco et al. 2008; Tinôco et al. 2010). These areas have been proposed in order to prevent further biodiversity loss due to the aforementioned impacts. Moreover, reptiles, specially snakes and lizards, apart from birds are the most affected biodiversity in this context.

Three-hundred-and-seventy-one species of snakes are described for the main Brazilian ecoregions (Bérnils 2010). One of the least known of those is the restinga. Rocha (2000) stated that reptiles are abundant in restinga ecosystems, and few studies cover the snake fauna in some regions, such as Jurubatiba in the state of Rio de Janeiro, where eight species were recorded over two years of study, and the Juréia in the state of São Paulo, where 25 snake species were recorded over a three-year study (Marques \& Sazima 2004), this re- inforces that there are few ecological studies of snakes in restinga areas. Most of the studies are restricted to the southeastern region of Brazil (Rocha \& van Sluys 2007) where biodiversity is mainly influenced by the Atlantic Forest alone specially on its coastal mountains, known as Serra do Mar. In northeastern Bahia, only Dias \& Rocha (2005) investigated the snake fauna in situ. They recorded 17 species for the whole restinga along the state's coast, but that included the southern coast of the federation unit. These numbers reveal the paucity of information about this taxon's richness and distribution in that area, and in the data required for assessing the actual conservation status of species of snakes within this ecosystem, especially in Bahia.

This scenario illustrates the poor knowledge on snakes within the region and, therefore, affects local stakeholders to establish their conservation strategies. This, compromises the creation of a proper action plan for the whole restinga ecoregion, that is in the agenda for new development projects and agriculture (Leão \& Dominguez 2000).

\section{MATERIAL AND METHODS}

\section{Study site}

The study was conducted at the Reserva Imbassaí, an integrated complex of tourism and real estate containing $132.73 \mathrm{ha}$ ( $\left.12^{\circ} 28^{\prime} 45.39^{\prime \prime} \mathrm{S} \& 37^{\circ} 57^{\prime} 32.94^{\prime \prime} \mathrm{W}\right)$. This is a modified natural area converted into a residential development site in the municipality of Mata de São João on the northern coast of Bahia, Brazil (Image 1), located in Bahia's Restinga Environmental Protection Area (Menezes et al. 2007). It is composed of four different vegetation types: beach habitat (BH), humid vegetation zone (HZ), scrub vegetation zone (SZ) and restinga dry forest (RF).

\section{Sample design}

We conducted six surveys between November 2008 and October 2009, with samples every two months and covering the four seasons, as part of the Reserva Imbassaí Long Term Monitoring Program (permit 03/2009-NUFAU-IBAMA-BA) begun in 2005. Each survey took four days and involved simultaneously sampling each of the four vegetation types.

At each site, we established a $200 \mathrm{~m}$ linear transect 

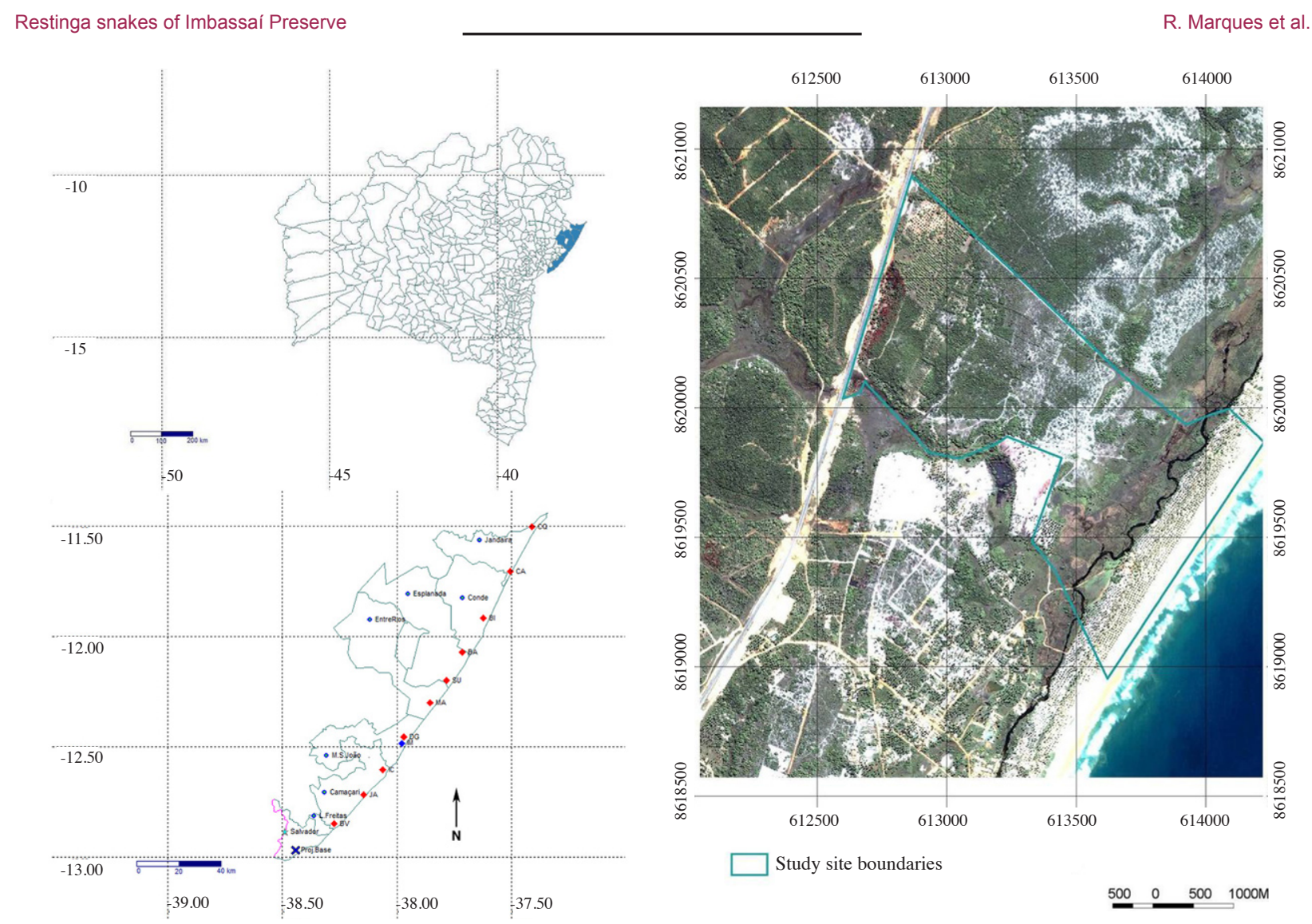

Image 1. Bahia State map, highlighting the northern coast of Bahia, surrounding the municipality of Mata de São João, with an aerial view of the Reserva Imbassaí.

(Krebs 1998) directed to the north, parallel to the seashore, and containing five sample points (SP) $50 \mathrm{~m}$ apart; there were 201 pitfall traps buried on the ground associated to $10 \mathrm{x} 0.4 \mathrm{~m}$ drift fences, providing a total of 720 hours of trapping effort.

We incorporated two hours visual encounter surveys (VES) along all transects, alternating between surveys, and covering from 0600 to $1800 \mathrm{hr}$ period. Two surveyors manually collected snakes, used hooks and snake tongs, or recorded sighted ones, identified and registered on a previously formulated protocol spreadsheet. Before, or after, the VES, the random encounter (RE) technique was applied, while walking to transect line. We also conducted five surveys at night, when VES was performed for two hours from 1900 to $2100 \mathrm{hr}$, summing 464 hours of effort. We confirmed the identity of the species according to Peters and Orejas-Miranda (1970) species identification key.

\section{RESULTS}

After one year of surveying, we registered 49 snakes from 15 species, distributed among five families: Boidae (Image 2), Colubridae (Image 3), Dipsadidae (Image 4), Elapidae and Viperidae (Image 5). Dipsadidae was the richest family, with six species represented, of which Philodryas nattereri Steindachner, 1870 was the most abundant species, followed by Oxyrhopus trigeminus Duméril, Bibron \& Duméril, 1854. Colubridae and Viperidae were represented by three species each, followed by Boidae with two species, of which Boa constrictor Linnaeus, 1758 was the third most frequent species of the study, while Elapidae was represented by only one species (Table 1).

\section{DISCUSSION AND CONCLUSIONS}

The species found are considered common in the region and only Crotalus durissus is listed as Least Concern in the IUCN Red List of Threatened Spe- 

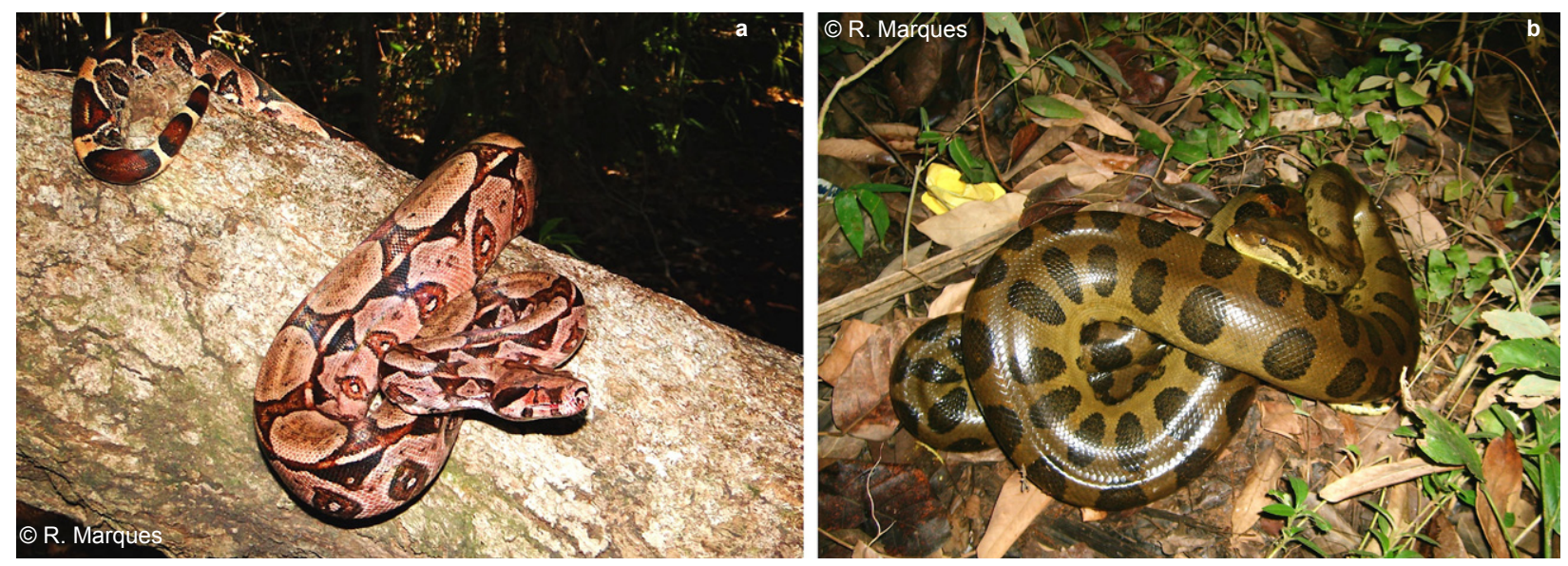

Image 2. Specimens of Boidae. a - Boa constrictor; b - Eunectes murinus.
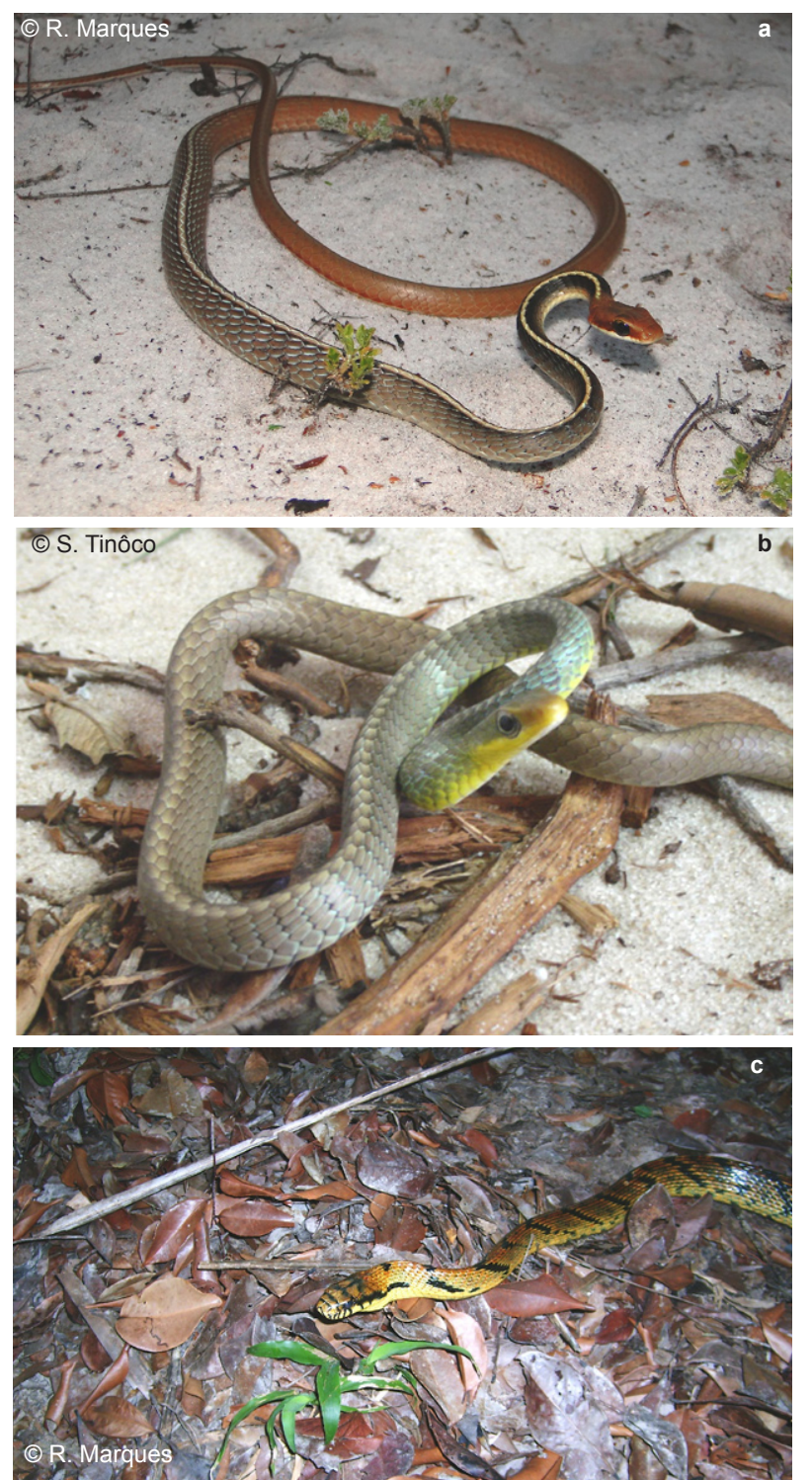

Image 3. Examples of colubrids.

a - Chironius cf. flavolineatus; $b$ - Chironius exoletus;

c- Pseustes sulphureus.
Table 1. Number of registered specimens of species of snakes found at Reserva Imbassaí on the northern Coast of Bahia. An asterisk (*) denotes new records for the northern coast of Bahia's restinga, $\left.{ }^{* *}\right)$ denotes new records for the Mata de São João municipality.

\begin{tabular}{|l|c|}
\hline Species & N \\
\hline Boidae & \\
\hline Boa constrictor Linnaeus 1758* & 7 \\
\hline Eunectes murinus (Linnaeus, 1758)* & 1 \\
\hline Colubridae & \\
\hline Chironius cf. flavolineatus (Boettger, 1885)* & 3 \\
\hline Chironius exoletus (Linnaeus, 1758) & 4 \\
\hline Pseustes sulphureus (Wagler, 1824) & 1 \\
\hline Dipsadidae & 1 \\
\hline Liophis cobella (Linnaeus, 1758)* & 1 \\
\hline Oxyrhopus trigeminus Duméril, Bibron \& Duméril 1854** & 7 \\
\hline Philodryas nattereri Steindachner, 1870** & 13 \\
\hline Philodryas olfersii (Lichtenstein, 1823) & 1 \\
\hline Philodryas patagoniensis (Girard, 1858) & 1 \\
\hline Taeniophallus occipitalis (Jan, 1863) & 1 \\
\hline Elapidae & \\
\hline Micrurus ibiboboca (Merrem, 1820) & \\
\hline Viperidae & 2 \\
\hline Bothrops leucurus Wagler, 1824 & \\
\hline Bothropoides jararaca Wied, 1824** & 2 \\
\hline Crotalus durissus (Linnaeus, 1758) & 1 \\
\hline
\end{tabular}

cies or in the Brazilian's Reptiles Red Book (Martins \& Molina 2008; IUCN 2011), however, some of the genera have other species listed in other regions such as: Chironius, Bothrops, Micrurus, Philodryas and Pseustes. Rocha et al. (2005) classified Bothrops leucurus as an endemic species of the central Atlantic 

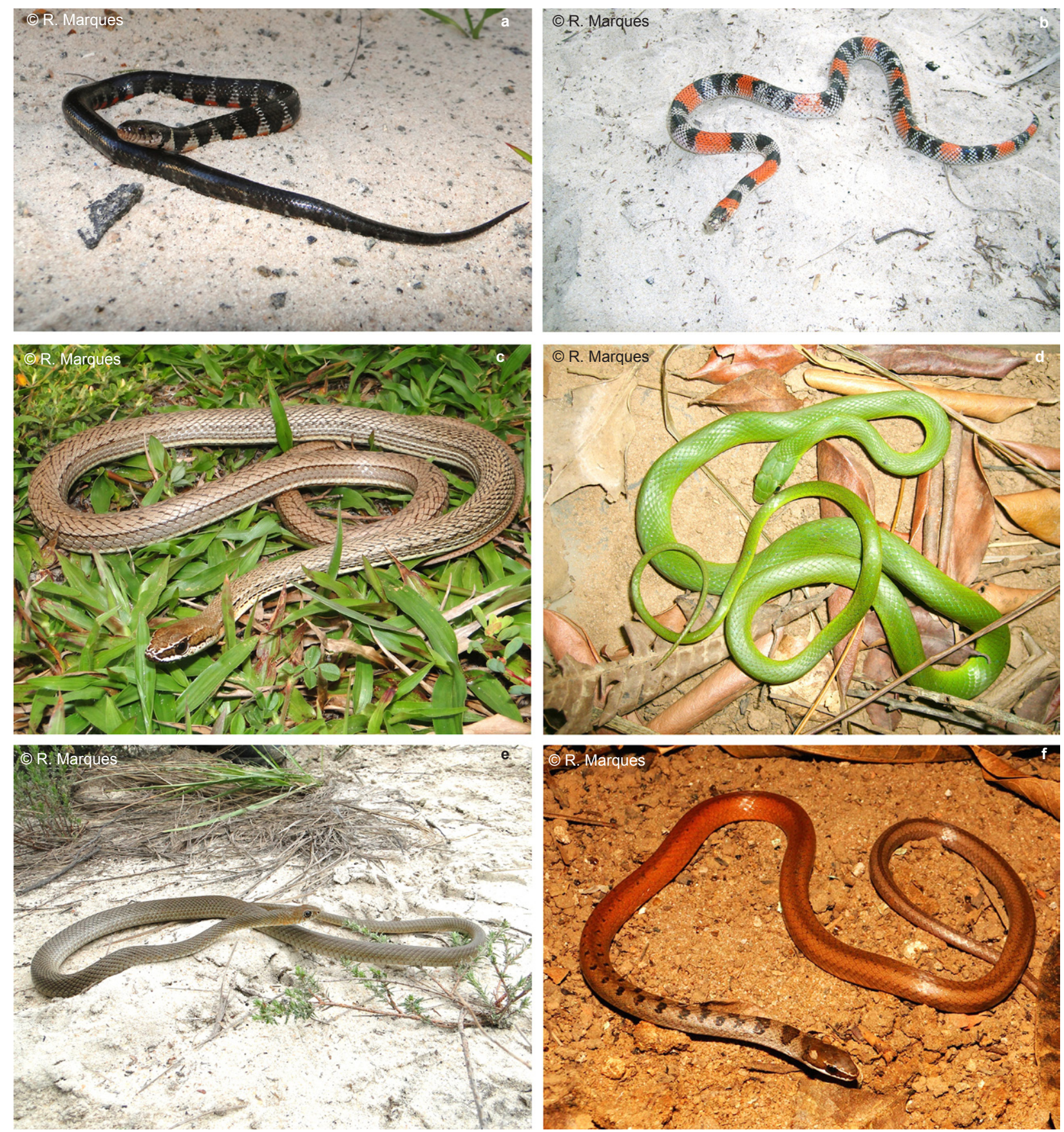

Image 4. Examples of dipsadids from the Reserva Imbassaí. a - Liophis cobella; b - Oxyrhopus trigeminus; c - Philodryas nattereri; d - Philodryas olfersii; e - Philodryas patagoniensis;
f - Taeniophallus occipitalis.

rainforest corridor and associated restinga ecosystems, among other herpetofaunal species, showing that the species also occur on the northern coast of Bahia. This might be a reflection of the poor knowledge available on the group's distribution and ecology within the region, and therefore we believe the conservation status might show important changes as studies develop over the years.
The literature, at present date lists 371 snake species as composing the snake fauna of the Brazilian territory (Bérnils, 2010). Dias \& Rocha (2005) registered 41 species of squamates along the coast of Bahia through visual encounter surveys and use of pitfall traps and snakes represented $41 \%$ of those species, of which eight were recorded from the northern coast of Bahia during a study of $2.160 \mathrm{hr}$ effort. Even 

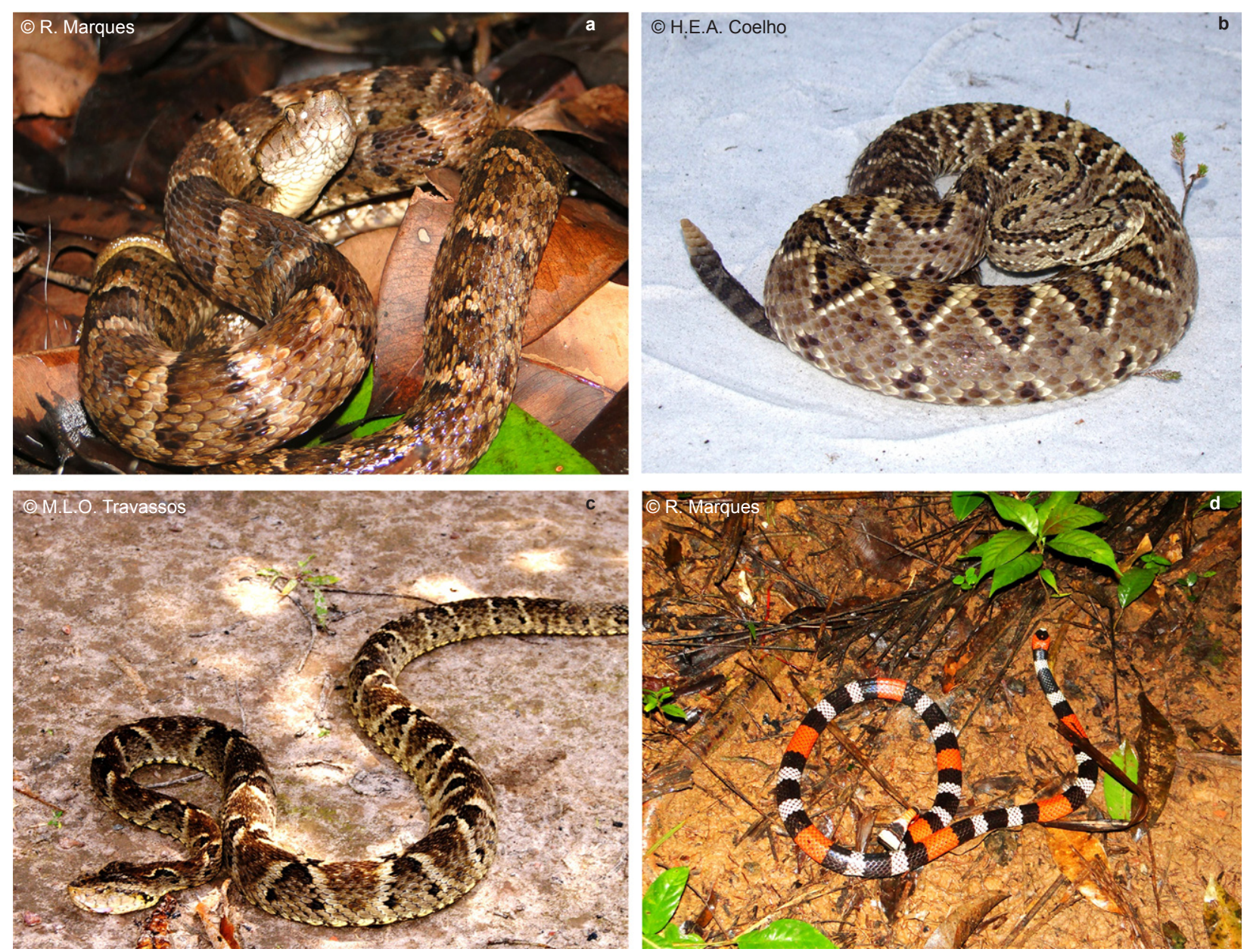

Image 5. Venomous snakes sampled in the study.

a - Bothrops leucurus; b - Crotalus durissus; c - Bothropoides jararaca; d - Micrurus ibiboboca.

though they sampled four different areas, our sample was conducted within an area of intense habitat loss, and 11 species found at Reserva Imbassaí are complementary to the list of snakes from the northern coast of Bahia's restinga. Ferreira et al. (2005) registered, in approximately one year, eight species from one restinga ecosystem in Maranhão, Brazil's northeast, using visual encounter surveys, pitfall traps and records from local communities, as sampling methods. Marques \& Sazima (2004) found 25 snake species at Juréia, southeastern Brazil, sampling in Atlantic forest and restinga, over three years, while Rocha et al. (2004) found eight species in two years at Jurubatiba's Restinga National Park (PNRJ), a 14.860ha area, 111 times larger than Reserva Imbassaí. Both studies used similar sampling methods and even more passive ones; we therefore consider that the studied site thus represent- a high richness spot for snakes in the Atlantic Forest and that this might be a result of the influ- ence of the contiguous Caatinga and Cerrado biomes. Comparison of these studies shows that the Reserva Imbassaí alone has a species richness similar to those sampled in other regions, except for Juréia in the State of São Paulo. In other studies on Cerrado, Sawaya et al. (2008) registered 36 snakes species and Recoder \& Nogueira (2007) registered 22 species; they sampled areas of 2,300ha and approximately $230,714 \mathrm{ha}$ respectively, while Ghizoni-Jr et al. (2009) registered 10 species from the highlands and the Santa Catarina coast. Considering the number of species, durations of study periods, and size of areas sampled, it could be argued that the snake fauna along the northern coast of Bahia's restinga are of great importance, especially if one considers that this region is classified as a high biological importance area (BRASIL 2002) and yet the status of snakes is generally unknown thus, the present study is an important addition to the knowledge of snakes and their applied conservation (Rocha 2000; 
Rodrigues 2005).

These results also show that the Reserva Imbassai contains a unique snake assemblage for a restinga ecosystem, even though severe environmental degradation and habitat loss, due to human development, has occurred over the past six years. In addition, venomous snakes were found within its boundaries and as a touristic and real estate complex, some measures should be taken to make people aware of the risk posed by the pitvipers, like Crotalus and especially species of the genus Bothrops, and thereby prevent or reduce the number of causalities from snake bite on the northern coast of Bahia (Mise et al. 2007). The inclusion of first reports of two species from this portion of the Brazilian territory should be highlighted. One is Bothropoides jararaca, sampled after the study period during this paper production, but an important addition to local fauna, for which literature reports its occurrence from Camaçari and a few other municipalities in Bahia, and from southeastern Bahia to Rio Grande do Sul. The specimen has been deposited at the Centro de Ecologia e Conservação Animal reference herpetological collection (CHECOA 002468). The second is the colubrid Pseustes sulphureus recorded in the Amazonian region and in the Atlantic rainforest from Ceará to Alagoas states and then from southeastern Bahia to São Paulo State (Campbell \& Lamar 1989; Argôlo 2004; Borges-Nojosa et al. 2006; Grazziotin 2006; Lisboa et al. 2009; Brazil 2010). The present paper fills in some of the distributional gaps for these taxa.

Although we present new records for some snakes, the status of these species remain unknown and highlights the need for long-term studies on Bahia's northern coast. Studies of populations, as well as of habitat use and natural history are needed to fill gaps in knowledge about these snakes, and to verify their status and ascertain whether they are affected by the anthropogenic changes in the restinga along Bahia's northern coast. Such efforts may aid the construction of effective management plans and contribute to the conservation of overall biodiversity.

\section{REFERENCES}

Argôlo, A. J. S. (2004). As serpentes dos cacauais do sudeste da Bahia. Ilhéus, Ba: Editus, 260pp.

Assumpção, J. \& M.T. Nascimento (2000). Estrutura e composição florística de quatro formações vegetais de restinga no complexo lagunar Grussaí/Iquipari, São João da Barra, RJ, Brasil. Acta bot. bras. 14(3): 301-315.

Bérnils, R. S. (org.). (2010). Brazilian reptiles - List of species. Accessible at http://www.sbherpetologia.org.br/. Sociedade Brasileira de Herpetologia. Captured on 17 September.

Borges-Nojosa, D.M., D. Loebmann, D.C. Lima, J.C.L. Melo \& A.C.G. Mai (2004). Reptilia, Colubridae, Pseustes sulphureus: distribution extension, new state record. Check List 2(3): 339-341.

BRASIL - Ministério do Meio Ambiente (2002). Avaliação e identificação de áreas e ações prioritárias para a conservação, utilização sustentável e repartição dos benefícios da biodiversidade nos biomas brasileiros. Brasília: MMA/ SBF, 404pp.

Brazil, T.K. (2010). Catálogo da fauna terrestre de importância médica da Bahia. Salvador: EDUFBA, 204p

Campbell, J.A. \& W.W. Lamar (1989). The Venomous Reptiles of Latin America. Ithaca. London, 425pp.

Campos, R.H.S. \& J.M.L. Domingez (2010). Mobility of sediments due to wave action on the continental shelf of the northern coast of the state of Bahia. Brazilian Journal of Oceanography 58(special issue PGGM): 57-63

Dias, E.J.R. \& C.F.D. Rocha (2005). Os répteis nas restingas do estado da Bahia: Pesquisa e ações para a sua conservação. Rio de Janeiro: Instituto Biomas, 36pp.

Ferreira, A.P., E.M.S. Fialho \& G.V. Andrade (2005). Composição e estruturação da comunidade de serpentes da restinga da praia de Panaquatira, Maranhão. VII Congresso de Ecologia do Brasil, Caxambú, 2pp.

Grazziotin, F.G., M. Monzel, S. Eheverrigaray \& S.L. Bonatto (2006). Phylogeography of the Bothrops jararaca complex (Serpentes: Viperidae): past fragmentation and island colonization in the Brazilian Atlantic Forest. Molecular Ecology (2006)15: 3969-3982.

Guizonni-Jr, I.R., T.S. Kunz, J.J. Cherem \& R.S. Bérnils (2009). Registros notáveis de répteis de áreas abertas naturais do planalto e litoral do Estado de Santa Catarina, sul do Brasil. Biotemas 22(3): 129-141.

IUCN. (2011). IUCN Red List of Threatened Species. Version 2011.1. www.iucnredlist.org. Downloaded on 18 September 2011.

Krebs, C.J. (1998). Ecological Methodology-2nd Edition. Benjamin Cummings, 581pp.

Leão, Z.M.A.N. \& J.M.L. Dominguez (2000). Tropical coast of Brazil. Marine Pollution Bulletin 41(1-6): 112-122.

Lisboa, B.S., I.C.S. Tiburcio, S.T. Silva \& G.O.S. Sugliano (2009). Primeiro registro de Pseustes sulphureus (Wagler, 1824) (Serpentes: Colubridae) no Estado de Alagoas, Nordeste do Brasil. Biotemas 22(4): 237-240.

Marques, O.A.V. \& I. Sazima (2004). História natural dos répteis da Estação Ecológica Juréia-Itatins, pp. 257-277. In: Marques, O.A.V. \& W. Dulepa (eds). Estação Ecológica Juréia-Itatins. Ambientes físico, flora e fauna. Ribeirão Preto, Holos, 384pp.

Martins, M. \& F.B. Molina (2008). Panorama geral dos répteis ameaçados do Brasil, pp. 326-377. In: Ministério do 
Meio Ambiente - MMA (Volume 1, Edition 1). Livro Vermelho da Fauna Brasileira Ameaçada de Extinção.

Menezes, C.M. (2007). A vegetação de restinga no Litoral Norte da Bahia, influência da evolução quaternária da zona costeira: estudo de caso fazenda Riacho das Flores, Mata de São João, Bahia. Master dissertation. Universidade Federal da Bahia, 96pp.

Menezes, C.M., M.S. Tinôco, S.M.H. Tavares, H.C. Browne-Ribeiro, V.S.A. Silva \& P.A. Carvalho (2007). Implantação, Manejo e Monitoramento de um Corredor Ecológico na Restinga no Litoral Norte da Bahia. Revista Brasileira de Biociências, Porto Alegre 5(supplement 1): 201-203.

Mise, Y.F., R.M. Lira-da-Silva \& F.M. Carvalho (2007). Envenenamento por serpentes do gênero Bothrops no Estado da Bahia: aspectos epidemiológicos e clínicos. Revista da Sociedade Brasileira de Medicina Tropical 40(5): 569-573.

Peters, J.A. \& B. Orejas-Miranda (1970). Catalogueof the Neotropical Squamata: Part I-Snakes. Washington, D.C., Smithsonian Institution, 347pp.

Recoder, R. \& C. Nogueira (2007). Composição e diversidade de Répteis Squamata na região sul do Parque Nacional Grande Sertão Veredas, Brasil Central. Biota Neotr. 7(3): 267-279.

Rocha, C.F.D. (2000). Biogeografia de répteis de restingas: Distribuição, ocorrência e endemismos, pp. 99-116. In: Esteves F.A. \& L.D. Lacerda (eds.). Ecologia de restingas e lagoas costeiras. Rio de Janeiro: Universidade Federal do Rio de Janeiro.

Rocha, C.F.D., M. Van-Sluys, D. Vrcibradic, F.H. Hatano, C.A. Galdino, M. Cunha-Barros \& M.C. Kieffer (2004). A comunidade de répteis da restinga de Jurubatiba, pp. 179-198. In: Rocha, C.F.D., F.A. Esteves \& F.R. Scarno (Orgs.). Pesquisas ecológicas de longa duração na restinga de Jurubatiba: ecologia, história natural e conservação. RiMa Editora, São Carlos, 376pp.

Rocha, C.F.D., M. Van-Sluys, H.G. Bergallo \& M.A.S. Alves (2005). Endemic and threatened tetrapods in the restingas of the biodiversity corridors of Serra do Mar and of the Central da Mata Atlântica in eastern Brazil. Brazilian Journal Biology 65(1): 159-168.

Rocha, C.F. \& M. Van Sluys (2007). Herpetofauna de restingas, pp. 44-65. In: Nacimento, L.B. \& M.E. Oliveira (Org.). Herpetologia no Brasil II. Belo Horizonte: Sociedade Brasileira de Herpetologia, 354pp

Rodrigues, M.T. (2005). Conservação dos répteis brasileiros: os desafios para um país megadiverso. Megadiversidade 1(1): 87-94.

Sawaya, R.J., O.A.V. Marques \& M. Martins (2008). Composition and natural history of a Cerrado snake assemblage at Itirapina, São Paulo State, southeastern Brazil. Biota Neotropica 8(2). Electronic Database accessible at http://www.biotaneotropica.org.br/v8n2/en/abstract?inventory+bn01308022008. Captured on 26 May 2010.

Tinôco, M.S., H.C. Browne-Ribeiro, R. Cerqueira, M.A. Dias \& I.A. Nascimento (2008). Habitat change and the amphibians conservation in the Atlantic Forest of Bahia, Brazil. Froglog 89: 1-3.

Tinôco, M.S., H.C. Browne-Ribeiro \& M.A. Dias (2010). The Bahian Sand Dunes Whiptail Lizard Cnemidophorus abaetensis Dias, Rocha \& Vrcibradic 2002 (Reptilia, Scleroglossa, Teiidae), geographic distribution and habitat use use in Bahia, Brazil. Herpetological Bulletin 111: 19-24.

Tonhasca Jr., A. (2005). Ecologia e historia natural da Mata Atlântica. Rio de Janeiro: Editora Interciência, $1^{\text {a }}$ Edição, 197pp.
Author Details: Ricardo Marques Biological Sciences undergraduate student and junior researcher at the Centro de Ecologia e Conservação Animal (ECOA), Universidade Católica do Salvador (UCSAL). Moacir Santos Tinôco Centro de Ecologia e Conservação Animal (ECOA) co-ordinator. Biodiversity Management PhD Candidate at the Durrell Institute for Conservation and Ecology, School of Anthropology and Conservation, University de Kent. Danilo Couto-Ferreira Biological Sciences undergraduate student and junior researcher at the Centro de Ecologia e Conservação Animal (ECOA), Universidade Católica do Salvador (UCSAL). Cecil Pergentino Fazolato Biological Sciences undergraduate student and junior researcher at the Centro de Ecologia e Conservação Animal (ECOA), Universidade Católica do Salvador (UCSAL). Henrique Colombini Browne-Ribeiro M.Sc. in Ecology and Biomonitoring at the Universidade Federal da Bahia (UFBA). Contributing researcher at the Centro de Ecologia e Conservação Animal (ECOA), Universidade Católica do Salvador (UCSAL). Magno Lima Travassos de Oliveira M.Sc. in Ecology and Biomonitoring at the Universidade Federal da Bahia (UFBA). Contributing researcher at the Centro de Ecologia e Conservação Animal (ECOA), Universidade Católica do Salvador (UCSAL). Marcelo Alves Dias M.Sc. in Zoology at the Programa de Desarrollo de las Ciencias Básicas (PEDECIBA), da Universidad de la RepublicaUruguay. Contributing researcher at the Centro de Ecologia e Conservação Animal (ECOA). João Victor Lino Mota Contributing researcher at the Centro de Ecologia e Conservação Animal (ECOA), Universidade Católica do Salvador (UCSAL).

Author Contribution: All authors are members and volunteers of the Long Term Restinga Herpetofauna Management and Monitoring Program at the northern coast of Bahia and have contributed to field work sampling in all surveys and the development of the current paper.

Acknowledgements: We would like to thank all researchers and volunteers of the Centro de Ecologia e Conservação Animal - ECOA and outside collaborators, who contributed to the implementation of this study. We also thank the organizations supporting this long-term management and monitoring program: the Reserva Imbassaí, Herpetofauna Foundation, Reptile Technologies and Lacerta Ambiental Ltda, for logistic support, hosting and providing equipment, during the study. 